\title{
TEMA-TEMA PENGALAMAN BERAGAMA PENGAMAL DZIKIR
}

\author{
Subandi \\ Universitas Gadjah Mada
}

\begin{abstract}
INTISARI
Penelitian ini bertujuan untuk mengidentifikasikan tema-tema pengalaman beragama yang dialami oleh orang-orang islam yang melaksanakan dzikir. Data penelitian diperoleh dengan wawancara mendalam terhadap tujuh orang pengikut kelompok Pengajian Tawakkal (PT) df Yogyakarta yang mengamalkan dzikir dalam hati dengan teknik tertentu. Data penelitian dianalisis secara kualitatif. Penelitian ini berhasil mengidentifikasi delapan belas tema pengalaman beragama, yang bisa diklasifikasikan dalam empat kelompok, yaitu pengalaman yang berhubungan dengan aspek fisiologis, sosial-psikologis, para-psikologis dan spiritual. Tema-tema tersebut mempunyai banyak kesamaan dengan tema pengalaman beragama pada pemeluk agama lain, tetapi ada beberapa tema yang spesifik muncul pada subjek penelitian.
\end{abstract}

Kata kunci : Pengalaman beragama, tipe pengalaman beragama, pengajian tawakkal, đzikir.

Subandi. lahir of Malang. Jawa Timur: adalah dosen Fakultas Psikologi UGM Yogyakarta. Lulusan program pasca sarjana Queensland University of Technology, Australia, ini menaruh minat yang kuat terhadap kajian-kajian psikologi dan psikoterapi agama. Menulis berbagai makalah dalam forum nasional maupun internasional. Saat ini juga aktif sebagai pengurus Yayasan Insan Kami! Yogyakarta.

\section{PENGANTAR}

D ada awal abad 20, ketika psikologi modern mulat muncul, sebenarnya telah banyak para ahli yang menaruh perhatian terhadap studi tentang pengalaman beragama. Salah satu studi yang sangat terkenal telah dilakukan oleh William James, yang sering jug a disebut sebagai salah satu pioner psikologi modern di Amerika. Studi William James tentang pengalaman beragama tersebut dijadikan sebagai bahan 
kuliah umum di Universitas Edinburg yang kemudian diterbitkan dalam sebuah buku yang berjudul The Varieties of Religious Experiences. Buku ini sangat populer dan dianggap sebagai salah satu tonggak penting dalam studi di bidang psikologi agama.

Pengaruh buku The Varieties of Religious Experiences memang cukup besar. Tetapi patut disayangkan pengaruh gerakan behaviorisme di Amerika waktu itu dernikian kuatnya sehingga para ahli psikologi mulai lebih banyak tertarik pada studi-studi psikologis yang bersifat objektif dan eksperimental daripada situdi tentang pengalaman manusia yang lebih bersifat subjektif. Walaupun demikian, tampaknya gerakan behaviorisme pada tahun 1970 an mulai sedikit berkurang pengaruhnya, terutama sebagai akibat dari pengaruh gerakan psikologi humanistik. Gerakan yang terakhir ini tampaknya ingin memberikan keseimbangan dalam psikologi supaya tidak terlalu bersifat positivistik dan behavioristik. Dalam perspektif psikologi humanistik inilah studi tentang pengalaman subjektif manusia mulai banyak diakukan kembali. Termasuk di antaranya adalah pengalaman beragama (religious experiences).

Menurut Glock (dalam Hayes, 1980), pengalaman beragama adalah suatu perasaan, persepsi atau sensasi yang dialami oleh seseorang dan didefinisikan oleh suatu kelompok/masyarakat sebagai suatu bentuk komunikasi dengan esensi Ketuhanan atau dengan realitas mutlak atau dengan otoritas transendental.

Menurut definisi of atas pengalaman beragama mengandung dua unsur. Pertama, adanya komunikasi dengan hal-hal yang bersifat ketuhanan atau transendental. Unsur ini dianggap oleh sebagian besar ahli sebagai aspek yang esensial dalam pengalaman beragama. Misalnya. Stark (1968) dengan tegas mendetinisikan pengalaman beragama sebagai suatu perasan berhubungan dengan sesuatu yang supernatural. Unsur kedua adalah adanya suatu konteks yaitu suatu kelompok/masyarakat yang memberikan legitimasi bahwa suatu pengalaman merupakan pengalaman beragama. Sejalan dengan itu Moore \& Habel (dalam Hayes, 1980) mengemukakan pentingnya pengalaman beragama sebagai suatu pengalaman dalam konteks suatu tradisi keagamaan tertentu.

Clark menambahkan unsur lain dalam pengalaman beragama, yaitu efek terhadap individu. a menganggap bahwa pengalaman merupakan suatu persepsi terhadap kosmos yang bersifat transendental dan yang disertai oleh perasaan-perasaan tertentu yang berakibat pada perubahan nifai-nilai dan perilaku (dalam Hayes, 1980).

Stark (1965) mengemukakan konsep tentang taksonomi pengalaman beragama dengan membagi pengalaman beragama dalam empat tipe, yaitu:

\section{(1). Tipeconfirming}

Di sini seseorang secara tiba-tiba mengetahui atau merasakan bahwa keyakinannya adalah benar. Termasuk dalam tipe ini adalah pengalaman seseorang tentang adanya suatu kesucian dan kesadaran akan kehadiran sesuatu yang bersifat ketuhanan.

\section{(2). Tipe responsive}

Di sini seseorang tidak hanya menyadari adanya kehadiran tentang sesuatu yang bersifat ketuhanan, tetapi orang tersebut jug a merasakan bahwa Tuhan memperhatikan dirinya. Termasuk dalam tipe ini adalah pengalaman merasa sebagai orang yang terpilih dan diselamatkan (salvationa), pengalaman intervensi Tuhan terhadap kehidupan keduniaan seseorang (miraculous) dan pengalaman intervensi Tuhan untuk menghukum atau mencegah seseorang berbuat kesalahan (sanctitioning). 


\section{(3). Tipe ecstatic}

Dalam tipe ini seseorang mendapatkan pengalaman keintiman dalam berkomunikasi dengan Tuhan. Seseorang tidak hanya merasa terpilin, tetapi dipenuhi rasa cinta pada Tuhan. Pengalaman ini biasanya disertai dengan kondisi psikis tertentu dan manifestasi tertentu. Misalnya perasaan bergelora, bahagia, damai, dan sebagainya.

\section{(4). Tiperevelational}

Di sini seseorang tidak hanya terpilih dan cinta kepada Tuhan, tetapi dia menjadi utusan Tuhan. Pengalaman ini pada umumnya hanya dimiliki oleh orang-orang yang dianggap Nabi oleh agama tertentu.

Margolif dan Elifson (1979) melaporkan hasil penelitian mereka setelah melakukan wawancara dengan 45 orang subjek tentang berbagai bentuk pengalaman beragama. Pengalaman-pengalaman beragama yang berhasit didentifikasi antara lain: perubahan persepsi terhadap realitas, perasaan aman, perubahan suasana pikiran dan perasaan, melihat atau mendengar sesuatu yang tidak kelihatan (visions and voices) pengalaman kehadiran atau keterikatan dengan Tuhan, perasaan damai. pengalaman berada di luar tubuh (out of body experience), perasaan bahagia dan bergelora (ecstasy), perasaan kesatuan segala sesuatu (unity), pengalaman berada dalam relitas/dunia lain dan pengalaman dalam mimpi yang berkartan dengan hal-hal di atas.

Dalam penelitian ini, pengalaman-pengalaman beragama yang telah disebutkan di atas dijadikan sebagai bahan referensi semata. Dengan demikian masih dimungkinkan adanya berbagai bentuk pengalaman baru yang spesifik ditemui pada subjek penelitian, yaitu anggota kelompok Pengajian Tawakkal yang melakasanakan dzikir dengan teknik tertentu.
Dzikiryang dilaksanakan dengan teknik tertentu pada dasarnya merupakan suatu bentuk meditasi. Meditasi mempunyai peranan yang sangat penting dalam kehidupan beragama seseorang. Hampir semua tokohtokoh besar pada setiap agama selalu mempraktekkan meditasi sebagai cara untuk meningkatkan kehidupan spiritual.

Pengalaman-pengalaman spiritual memang banyak ditemui oleh orang-orang yang melaksanakan meditasl. Banyak penelitian yang mengungkapkan bahwa meditasi merupakan suatu cara yang paling efektif untuk mencapai altered states of consciousness, yaitu suatu kondisi kesadaran yang berubah, yang berada di luar kesadaran bisa (Ornstein, 1986:Waish, 1983). Dengan kondisi kesadaran seperti inilah pengalaman spiritual, atau sering juga disebut sebagai pengalaman-pengalaman mistis (mystical experiences), muncul.

\section{METODE PENELITIAN}

\section{A. Subjek}

Subjek penelitian ini adalah para pengikut kelompok pengajian Tawakkal di Yogyakarta. Secara harfiah dzikir berarti ingat. Dalam hal ini yang dimaksud adalah ingat kepada Allah. Meskipun perintah dzikursecara jelas memang banyak disebutkan dalam berbagai ayat di dalam Al Qur'an, tetapi tidak ada bentuk yang spesifik mengenai bagaimana cara melaksanakan dzikir. Ada banyak bentuk amalan dzikir. Pelaksanaan seluruh ibadah yang diperintahkan Allah (khususnya yang terdapat dalam rukun islam: syahadat, sholat, zakat, puasa dan haji) sebenarnya merupakan bentuk dzikir. Tetapi secara khusus dzikir adalah amalan dilaksanakan dengan membaca kalimat-kalimat tertentu, misalnya tasbih (subhanalloh) tahmid (alhamdulliah), takbir (Allohuakbar), tahlil (Iga ila ha illallah). Termasukjuga mem- 
baca ayat-ayat suci Al Qur'an. menyebut nama-nama Allah yang indah (asmaul husna) maupun membaca doa-doa yang diajarkan oleh Nabi Muhammad saw.

Selain kalimat dzikir berneka macam, teknik melaksanakan juga beragam. Secara umum, pelaksanaan amalan dzikir dapat $d j$ bagi dua. Pertama. adalah dzikir yang diucapkan dengan lisan (dzikir bilfisan), atau ada juga yang menyebut dengan dzikirjahar. karena diucapkan dengan suara yang keras. Kedua, adalah dzikir yang diucapkan dalam hati (dzikir bil golbr). Teknik dzikir yang terakhir inilah yang dilaksanakan oleh anggota kelompok Pengajian Tawakkal yang menjadi subjek penelitian ini.

Amalan dzikirdalam pengajian tawakkal dapat dilaksankan secara individual ataupun dalam pertemuan kelompok. Pada dzikirke. lompok. salah seorang anggota atau pimpinan pengajian sendiri, bertugas sebagai pembimbing yang mengarahkan jalannya dzikir kelompok. Dzikir ini dilaksanakan dengan posisi duduk bersila, dengan tubuh menghadap ke Ba rat (kiblat). Bacaan yang pertama kali diucapkan adalah kalimah syahadat, yaitu persaksian bahwa tidak ada Tuhan selain Allah dan bahwa Nabi Muhammad adalah utusan Allah. Bacaan ini diucapkan secara keras oleh pembimbing dzikir dan para peserta mengikuti mengucapkan dalam hati. Bacaan yang kedua adalah sholawat, yaitu do'a untuk Nabi Muhammad, kemudian dilkuti dengan membaca beberapa surat pendek dalam AI Qur'an. Baru setelah itu memasuki amalan dzikirdengan menyebut nama-nama Tuhan, baik nama Allah sendiri maupun beberapa asma-ul husna (nama-nama Allah yang baik). Asmaui husna yang sering diucapkan adalah Ya Rah. man, Ya Rahim (Wahai Yang Maha Pengasih, Yang Maha Penyayang), Ya Malik, Ya Ouddus (Wahai Maha Raja, Yang Maha Suct), Ya Fattah, Ya Razaq (Wahai yang membukakan, yang memberi rejeki) dan sebagainya. Semuanya diucapkan dalam hati.

Amalan dzikir ini berlangsung selama satu atau dua jam. Sebelum selesai, pembimbing dzikirmeminta peserta untuk membaca surat alfathah dan kemudian membaca alhamdulilah (segala puji bagi Allah) dan kemudian mengusap seluruh badan dengan tangan.

\section{B. Metode Pengumpulan Data}

Metode pengumpulan data yang digunakan dalam penelitian ini adalah metode wawancara mendalam yang bersifal dialogis. Metode ini beranggapan bahwa subjek penelitian bukan sekedar sumber data, tetapi sebagai manusia yang utuh. Oleh karena itu, metode ini menekankan pada dia$\log$ antara peneliti dan subjek sebagai dialog antara manusia satu dengan yang lain. sehingga meskipun pedoman wawancara juga dibuat, tetapi sitatnya tidak mengikat. Dengan kondisi seperti ini diharapkan subjek penelitian dapat mengungkap selurun pengalaman yang pernah dialami, tanpa ada penghambat. Untuk mendapat variasi pengalaman maka tiga variabel dipertinıbangkan dalam pemilihan subjek, yaitu: Umir, lamanya melaksanakan dzikirdanjenis kelamin.

Metode wawancara dialogis ini dipilih mengingat bahwa pengalaman religius merupakan pengalaman yang bersifat pribadi, sehingga hanya kepada orang yang telah diberi kepercayaan saja seseorang mau menceritakan. Seluruh wawancara dialogis dengan subjek penilitan direkam dengan sebuah tape-recorder.

Wawancara dilakukan terhadap 7 (tujuh) orang subjek yang terdiri dari empat orang pria (dengan inisial ND, MA, AG, SU) dan 3 orang wanita $(\mathrm{BD}, \mathrm{BS}, \mathrm{BM})$ dengan variasi Umur mulai umur 20-an sampai 50 -an, sedangkan tarnanya melaksanakan dzikir bervariasi, mulai kurang dari 5 tahun sampai 
20tahun.

\section{Metode Analisis Data}

Metode kualitatit dilaksanakan untuk mengolah data dengan langkah-langkah sebagai berikut:

1. Transkripsi wawancara.

2. Mengidentitikasi tema-tema pengalaman-pengalaman religius yang muncul. Detinisi yang dijadikan pedoman adalah sebagai berikut: Tema adalah suatu ide yang dapat berdiri sendiri, yang muncul dari pernyataan subjek yang baik secara langsung maupun tidak langsung.

3. Klasifikasi pengalaman religius. Dasar klasifikasi ini adalah adanya persamaan ide yang mendasari satu tema dengan tema pengalaman yang lain.

\section{HASIL PENELITIAN}

\section{A. Tema-tema Pengalaman Beragama}

Dari hasil pengolahan data diperoleh 18 tema pengalaman beragama di bawah ini. Setiap tema yang dipaparkan disertai salu atau dua kutipan langsung dari pernyataan subjek yang mendukung tema tersebut.

\section{Timbulnya gerakan-gerakan otomatis}

Beberapa subjek mengungkapkan pengalamannya yang berkaitan dengan timbulnya gerakan-gerakan tubuh yang otomatis. Mereka pada umumnya menyebutkan bahwa mereka menyadari sepenuhnya apa yang sediang ter jadi, tetapi tidak mampu mengendalikan gerakan itu. Ada kekuatan lain yang menguasai diri mereka. Pengalaman ini pada umumnya timbul ketika subjek masin baru beberapa kali melaksanakan dzikir. seperti tampak pada ungkapan d bawah ini:

"Sesudah itu tibartiba saya ingin berdiri. Tapi yang ingin itu bukan otak. Kollihat- annya menyeluruh. Tiba-tiba otot kaki menyebabkan saya berdiri, sehingga berdiri rasanya ringan. Waktu itu saya dalan keadaan sadar penuh. Lalu rasanya tangan saya mengangkat sendin seperti orang shalat. Pada saat akan membungkuk, badan itu membungkuk sendiri, lalu sujud". (MA)

\section{Penyucian diri}

Ketika dzikir telah mulai masuk ke dalam hati, banyak subjek yang mengungkapkan bahwa mereka mengalami proses penyucian diri dar hal-hal yang tidak dibenarkan oleh agama, yang pernah mereka perbuatan sebelumnya. Tema pengalaman ini pada umumnya berkaitan dengan tema 1, yaitu timbulnya gerakan otomatis, tetapi ada juga yang mempunyai bentuk yang lain.

"Waktu itu saya dibersihkan. Karena kotoran saya banyak, penyuciannya juga keras. Gerakan-gerakan silat saya keluar semua"..(ND)

*... Saya malah kena penyakit kulit. Seluruh badan saya gatal. Ini berbeda dengan pada umumnya orang Ikut PT yang justru bisa sembuh penyakitnya sotelah dzikir. Menurut teman saya its mungkin merupakan pembersihan din saya dari syirik-syirik kecil". (MA)

\section{Penemuan kebenaran}

Beberapa subjek mengungkapkan bahwa mereka menemukan bukti-bukti tentang kebenaran ajaran agama yang pernah diperoleh sebelumnya. Khususnya berkaitan dengan ayat-ayat al-Qur'an, sebagian besar subjek mendapatkan pengalaman langsung. Apa yang disebutkan dalam al-Qur'an itu mereka temui dalam kehidupan nyata seha. ri-hari. Dengan demikian keimanan mereka menjadi lebih mantap, bahwa apa yang dise. 
butkan dalam al-Qur'an itu memang benar. Misalnya:

".. Qur'an memang terbukti kebenanya. Saya lebih mantap". (BM)

"Banyak saya menemukan kebenarankebenaran AV Qur'an". (AG)

"Saya menjadi mantap [bahwa islam] adalah jalan saya Sekarang saya menjadi [orang] islam beneran". (BD)

\section{Pemahaman baru tentang ajaran-ajaran agama}

Subjek penelitian ini pada umumnya telah mendapatkan pendidikan agama sejak kecil, walaupun dengan intensitas yang bervariasi. Mereka telah sejak lama melaksanakan ibadah ritual atau telah mengerti suatu ajaran tertentu. Tetapi setelah melaksanakan dzikir, mereka melaporkan bahwa mereka mendapatkan pemahaman dengan dimensi pemahaman yang baru pada materi ajaran yang sama. Oleh karena itu seorang subjek (BS) membedakan antara proses "mengetahui" dan "mengerti" suatu ajaran tertentu.

"Tadinya saya sudah pernah membaca ayat itu tapi hanya sampai di otak. Seka rang saya bisa merasakan kebenarany $a^{\prime \prime}(\mathrm{AG})$

"Dulu saya sudah tahu tentang penyakit-penyakit hati, seperti hasad, dengki dan sebagainya. Tapi sekarang menger. i kalau yang namanya benci itu begitu. Jadi dulu tahu artinya tapi tidak menger$t^{m}$ (BS)

\section{Keakraban dan kedekatan dengan \\ Tuhan}

Terna ini terungkap dari pernyataan subjek secara langsung tentang kedekatannya dengan Tuhan. Juga tercermindari pernya- taannya yang menunjukkan adanya hubungan yang akrab, seperti disayangi, dimarahi, dijewer atau berdialog secara pribadi dengan Tuhan.

"Sepertinya saya dijewer [Allah]: "Kamu itu mengertilah!". (BM)

"Jadi say a merasa man tap. Kalau begitu Allah itu menyayangi saya ...". (BD)

"... saya berdialog dengan Allah". (AG)

Hubungan keterdekatan juga dari ungkapan yang menggambarkan adanya perasaan ketergantungan penuh terhadap Tuhan-

"Rasanya ada ketergantungan penuh." (SU)

\section{Transisi}

Di sini subjek secara langsung atau tidak langsung menyatakan bahwa terjadi masa transisi antara sebelum dan sesudah melaksanakan dzikir. Transisi itu bisa ditandai dengan perubahan kehidupan yang terjadi secara drastis. Perubahan tersebut dapat berupa peningkatan ibadah yang luar biasa.

"Kemudian saya dirajinkan dan disenangkan untuk mendatangi pengajian dzikir. Itu transisi saya. [Pada waktu itu] saya merasa (kehidupan beragama sayaj meningkat. Allah membuat saya ingin selalu menambah ibadah, seperti puasa [dan] shalat". (BM)

Transiși dapat pula berbentuk sikap atau tingkah laku religius yang jauh berbeda dengan keadaan sebelumnya. Misalnya meninggalkan kehidupan dunia.

"Saya acuh [lerhadap dunia]. Saya tidak mau nonton fim atau mendengar musik. Saya merasa seolah-olah dunia in tak ada artinya" (AG) 
Namun demikian, peristiwa transisi ini pada umumnya hanya terjadi dalam waktu yang tidak terlalu lama. Setelah itu subjek kembali dalam kondisi normal dengan dimensi kehidupan baru.

\section{Peningkatan ritual ibadah}

Tema ini ditunjukkan dengan laporan subjek yang menunjukkan bahwa pelaksanaan ibadah ritual mereka seperti shalat, puasa, membaca al-Qur'an, dzikir meningkat setelah melaksanakan dzikir. Tema ini tampak menonjol pada masa transisi. Sikap mereka terhadap ibadah ritual tersebut jug a berubah. Yang semula ibadah ritual dipandang sebagai beban menjadi șuatu kenikmatan.

"Allah membuat saya ingin selalu menambah ibadah, seperti puasa [dan] shalat. Saya sampai keranjingan beriba dah". (BM)

"... saya menjadi senang shalat. Tadinya shalat lima waktu saja seperti beban, sekarang menjadi nikmar kemudian timbul keinginan shalat sunnat". (MA)

\section{Hilangnya rasa ke-aku-an}

Sebagian subjek melaporkan adanya pengalaman bahwa ke-aku-an mereka hilang atau berkurang, Rasa "aku" ini sering diasosiasikan dengan kesombongan, merasa pintar, merasa jadi orang penting atau merasa bisa, tanpa menyadari adanya keterbatasan diri. Di sini subjek justru merasa tıdak bisa apa-apa, tidak memiliki apa-apa, bahkan ada yang merassa tidak ada. Pengalaman ini dapat berupa suatu kondisi sesaat (stare) atau menetap.

"Saya sekarang betul-betul [merasa] tiolak punya apa-apa". (ND)

"Suatu saat Allah memberi saya suatu kondisi fof mana] 'aku saya itu turun....
'Aku' saya menjadi semakin turun'. (BM)

"Tidak tahu saya di mana. Jadi saya merasa hilang". (BD)

\section{Pengalaman penyembuhan (healing experience)}

Beberapa subjek penelitian menyebutkan adanya pengalaman yang berkaitan dengan kesembuhan pada waktu melaksanakan dzikir. Kesembuhan tersebut dapat terjadi pada diri sendiri, atau untuk kesembuhan orang lain.

"Suatu saat ambeien saya kumat. Lalu saya coba dzikir sendiri. Setelah dzikir khusu: badan saya bergerak [sendiri] seperti orang melakukan olahraga. Alhamdulillah kemudian bisa sembuh". (MA)

"Waktu ilu saya hanya membantu mendoakan, tapi liba-tiba seperti ada aliran listrik yang keluar dari tangan saya lalu memancar ke targan or ang yang sakit". (MA)

Bagi sebagian besar subjek, pengalaman kesembuhan dan penyembuhan bukan dianggap sebagai suatu kemampuan yang mereka miliki, karena mereka hanya sebagai mediator saja. Maka bis a jadi suatu saat merekadapat memberikan kesembuhan, tetapi saat yang lain tidak bisa. Hai ini tergantung pada kondisi psikologis dalam diri mereka sendiri. Terutama berkaitan dengan munculnya kondisi di mana tidak ada rasa "aku".

\section{Pengalaman yang sulit diungkapkan secara verbal(ineffable)}

Banyak subjek yang merasa kesulitan dalam mengungkapkan seccara verbal suatu pengalaman spesitik yang subjektif yang dialaminya, karena pengalaman tersebut berkaitan dengan alam perasaan atau peng- 
alaman kerohanian yang sulit digambarkan. Oleh karena itu subjek pada umumnya atau menggunakan kata-kata tertentu untuk mengungkapkan pengalaman tersebut.

"Pada waktu itu saya merasakan plong. Rasanya saya berubah menjadi orang baru". (MA)

"Rasanya enak seperti los. Rasanya seluruh pori-pori atau sel tubuh itu ikut bedzikir". (SU)

"Sepertinya dada saya itu ierbuka. Rasanya seperti terbang. Tak tahulah [bagaimana saya harus menceritakan]. Pokoknya terbuka semua". (BD)

\section{Pengalaman menjangkau masa depan}

Beberapa subjek mengungkapkan adanya pengalaman yang dapat menggambarkan kejadian yang akan datang. Pengalaman ini dapat terjadi melalui impian atau pandangan mata batin ketika sedang melaksanakan dzikir. Pada umumnya subjek baru menyadari bahwa pengalaman itu memiliki nilai prediktif, ketika kejadian yang pernah dilihatnya itu terjadi di dalam realitas.

"Sewaktu Pak T mau meninggal, saya sudah tahu. Saya melihat ketika dzikir. ada ruang tamu kosong. Di situ ada peti jenazah. Saya ihat Bu T sendirian. Lalu ada suara: "ftu Pak T", (BD)

"Di dalam mimpi itu saya melihat keluarga saya [sedang menghadapi masalahi. Saya mimpi hari Sabtu kejadianya hari Minggu". (SU)

12. Pengalaman yang berhubungan dengan problem kehidupan sehari-hari

Selain berkaitan dengan kehiduparn spiritual dan religius, banyak juga pengalaman subjek yang menjangkau problematika kehidupan sehari-hari, baik secara ekonomis, emosional ataupun sosial. Mereka merasa adanya intervensi dari kekuatan di luar dirinya dalam menghadapi masakah kehidupan sehari-hari.

"Saya merasa banyak ditolong Allah. Rejeki tidak kurang, dan anak-anak itdak mengalami trauma (meskipun berpisah dengan ayahnyaf". (BS)

Ada juga subjek yang merasakan perubahan sikap yang lebih positif dalam menghadapi pernasalahan kehidupan sehari-hari.

"Sekarang kami tidak banyak pikiran dan dapat mensyukuri segala rahmat... Kai zu dimarahi orang iebih baik minggir saja. Saya anggap sebagi ujian saja". (ND)

\section{Pembaharuan moralitas}

Perubahan dalam diri subjek juga terjadi dalam aspek moralitas. Mereka mengungkapkan adanya perubahan tingkah-laku moral antara sebelum dan sesudah melaksanakan dzikir. Termasuk di sini adalah hilangnya sifat-sifat buruk yang mereka miliki sebelumnya. Alau berhentinya subjek melakukan pertuatan yang termasuk dalam kategori berdosa dipandang dari segi ajaran agama.

"Pikiran dan hati saya tidak ada rasa macam-macam. Tadinya mungkin suka ini, dengki. Itu hilang semua. Lapang sekali dada inim..(MA)

"Bau kemudian saya sadari kalau saya banyak melakukan perbuatan dosa. Saya memberi makan anak saya dengan "batu, pa sir, semen dan kapur" yang saya curi dari proyek. Logikanya [kalau] perut disi [barang] seperti itu, mestinya [akan] membikin sakit". (ND) 


\section{Gangguan dari makhluk lain}

Beberapa subjek melaporkan bahwa mereka mendapatkan gangguan ketika mereka berusaha mendekatkan diri pada Allah. Gangguan tersebut oleh beberapa subjek diidentifikasi sebagai dari makhluk halus secara um um, tanpa menyebutkanjenis yang khusus. Sebagian subjek mengidentifikasi secara spesitik gangguan tersebut adalah dan mahlukjin. Pengalaman ini pada umumnya terjadi ketika subjek mengalami masa transisi, di mana intensitas ibadah nitualnya meningkat.

Bentuk gangguan sangat bervariasi pada setiap individu. Ada yang mendapat gangguan melalui penglihatan, yaitu pada subjek diperlihatkan hal-hal yang menakutkan. Dapat juga dalam bentuk pendengaran suara-suara yang aneh, atau dalam bentuk impian yang mengerikan. Ada juga seorang subjek yang mendapat gangguan melalui intervensi secara fisik.

"... mulai ada gangguan. [Kelika] saya takbir akan meneruskan shalat dluha, badan saya diputar seperti gangsingan. Saya tidak bisa melawan, karena kuat sekali. Esok harinya ketika saya akan mengambil air wudlu untuk shalat subuh, timbanya melilit beberapa kali. Saya mulai khawatir ketika pagi-pagi subuh itu gelas-gelas yang ada of rak piring pecah meledak". (MA)

\section{Pengalaman yang berkaitan dengan perubahan kesadaran atau alrered states of consciousness (ASC)}

Beberapa subjek penelitian ini melaporkan adanya pengalaman yang dapat dikategorikan sebagai pengalaman Altered States of Consciousness (ASC), yaitu suatu pengalaman adanya perubahan kesadaran dalam diri seseorang dari kesadaran normal kehidupan sehari-hari ke kesadaran yang lain. Hal ini tercermin dari pengalaman subjek yang dapat mengalami hal-hal yang tidak bisa dialami oleh orang normal.

"ISaat] itu saya [uga] diberi Allah ke. tajaman bashiroh [mata hati]. Saya bisa "melihat orang". Pernah saya bertemu dengan orang yang wajahnya berubah jadi anjingatau babi". (ND)

Termasuk pengalaman ASC ini adalah pengalaman yang berupa penglihatan ( $\mathrm{Vi}$ sions), pendengaran (voices), atau pengalaman terlepas dari ikatan dimensi ruang dan waktu.

"Di situ saya merasakan suatu peng" alaman rohani. Saya melihat suatu taman yang sangat indah. Ada bungabunga. Pengalaman itu betul-betul mempengaruhi hidup saya". (BM)

"Sualu ketika setelah selesai shalat ashar, tiba-tiba saya mendengar suara seperti orang laki-lakijelas sekali: "Ka" mu itu kok mubadzir, menyebut-nyebut nama Allah. Allah itu tidak ada". (BM)

"Saya pernah mengalami terbang. Setelah maghnb saya dzikir of masjid agak lama. Tiba-tiba [saya] sudah sampai d atap. Saya melihal diri saya di bawah sedang dzikir sambil duduk. Saya terkejul dan lakur. Tapi akhimya saya bisa kembali. Saya juga pernah masuk ke bumi",

\section{Pengalaman yang berkaitan dengan} suasana emosi

Terna pengalaman ini terlihat dari ung kapan yang menunjukkan adanya berbagai macam perasaan yang muncul dalam diri subjek. Termasuk di sini adalah munculnya perasaan berdosa, rasa sedih, gembira, bahagia dan sebagainya. Pengalaman ini dapat timbul berkaitan dengan amalan dzikir, baik secara langsung maupun tidak langsung. 
"Kejadian itu sangat memukul saya. [Saya merasa] betul-betul kurang ajar pada Allah. Saya merasa sangat berdosa, karena sudah diberi jawaban sungguh-sungguh, tapi mengingkari janjr. (BD)

"Pada waktu awal-awalnya saya sering menangis kalau dzikir. Teringat dosadosa masa lalu dan takut pada Allah... Kalau mendengar adzan sering menangis". (AG)

\section{Perasaan diaturoleh Tuhan}

Selain mengungkapkan keterdekatan hubungan dengan Allah seperti terlihat pada tema 5 , beberapa subjek juga mengungkapkan adanya perasaan bahwa kehidupan mereka telah diatur oleh Allah. Baik yang menyangkut masalah-masalah besar dalarn kehidupan mereka, maupun menyangkut masalah-masalah kecil dalam kehidupan sehari-hari. Mereka memiliki kuasa untuk mengafur diri sendiri, tetapi mereka juga merasakan adanya yang Maha Pengatur.

"Saya punya kehendak, tapi saya merasa kehendak Allah yang berlaku. Allah Maha mengatur. Semestinya saya bersikap seperti wayang yang patuh terha dap segala perintah dalang. Saya merasa betul seperti wayang". (BD)

\section{Mendapatkan petunjuk dari Tuhan}

Sebagian besar subjek mengungkapkan adanya pengalaman bahwa mereka mendapatkan petunilukdari Tuhan. Petunjuk tersebut dapat melalui ayuat-ayat AN Qur'an. atau berupa isyarat-isyarat inderawi, maupun kejadian sehari-hari.

"Jadi saya hanya mohon petunjuk pada Allah Logikanya, Allah Maha tahu dan Kalau Allah berkenan saya akan oibentahu [dengan is yarat]. Isyarat itu bisa gerak, penglihatan atau rasa" (MA).

"Jadi Allah memberi petunjuk sampai sekecil-kecilnya. Peristiwa yang sepele [bagi orang lain] besar atinya bagi saya, karena menghasilkan petunjuk yang besar. (BM)

\section{B. Klasifikasi Tematema}

Berdasarkan kesamaan isi dari tematema pengalaman beragama yang telah disebutkan, maka tema-tema telah disebutkan di atas dapat diklasifikasikan sebagai berikut:

1. Pengalaman fisiologis, yaitu pengalaman yang mencakup tema-tema: (1) timbulnya gerakan otomatis, (2) penyucian diri dan (9) pengalaman penyembuhan.

1I. Pengalaman sosial-psikologis, yang mencakup tema: (6) transisi. ( 8 ) hilangnya rasa ke-aku-an, (10) pengalaman yang sulitdiungkapkan, (12) pengalaman yang berhubungan dengan problem kehidupan sehari-hari dan ( $\$ 6$ ) pengalaman yang berkaitan dengan suasana emosi.

III. Pengalaman para-psikologis, yang mencakup terna (11) pengalaman yang menjangkau masa depan, (14) gangguan dari makhluk halus dan (15) pengalaman yang berkaitan dengan perubahan kesadaran atau Altered States of Consciousness (ASC).

N. Pengalaman spiritual/kerohanian, yang mencakup terna (2) penyucian diri, (3) penemuan kebenaran, (4) pemahaman baru tentang ajaran agama, (5) keakraban dan kedekatan dengan Tuhan, (7) peningkatan ritual ibadah, (13) pembaharuan moralitas, (17) perasaan diatur oleh Tuhan dan (18) mendapatkan pefunjuk Tuhan. 


\section{PEMBAHASAN}

Hasil penelitian ini menunjukkan bahwa pengalaman beragama (religious experiences) subjek, yaitu orang Islam yang melaksanakan dzikir dengan teknik tertentu, mempunyai banyak kesamaan dengan pengakaman beraga ma yang diungkap dalam beberapa literatur psikologi agama.

Tipe confirming, menurut Stark (1965), d mana orang merasa bahwa apa yang diyakini adalah benar, dalam penelitian ini terlihat pada tema: (3) penemuan kebenaran dan (4) pemahaman baru tentang ajaran agama. Tipe responsiveyang menun jukkan adanya intervensi Tuhan terhadap kehidupan seseorang terlhat pada tema: (12) pengalaman yang berkaitan dengan problem kehidupan sehari-hari. Tipe ecstatic yang menunjukkan hubungan keintiman dalam berkomunikasi dengan Tuhan tampak pada tema: (5) keakraban dan kedekatan (17) perasaan diatur oleh Tuhan dan (18) mendapatkan petunjuk Tuhan.

Dibandingkandengan pengalaman beragama hasil penelitian Margolif dan Elifson (1979), pengalaman beragama subjek penelitian juga banyak persamaannya. Misalnya adanya perubahan persepsi terhadap realitas terlihat pada tema (2) penyucian dir di mana seorang subjek mengungkapkan bahwa penyakit kulit yang diderita bukan karena masalah medis, tetapi sebagai suatu bentuk penyucian diri dari dosa-dosanya. Perubahan suasana perasaan tampak pada tema (16) pengalaman yang berkaitan dengan suasana emosional d mana subjek penelitian merasa sedih, gembira atau berdosa ketika melaksanakan dzikir. Demikian juga pengalaman berupa penglihatan ( $v$ ision) dan pendengaran (voices) maupun out of body experience jelas terungkap dalam tema yang tercakup dalam klasifikasi pengalaman para-psikologis.

Kesamaan pengalaman beragama yang diungkapkan di atas menunjukkan bahwa meskipun subjek penelitian ini mempunyai latar belakang tradisi keagamaan yang berbeda dengan penelitian sebelumnya, ternyata tema-tema pengalaman beragama yang muncul banyak kesamaannya. Dengan demikian dapat disimpuikan bahwa pengalaman beragama ternyata tidak terikat oleh agama yang dianut seseorang.

Di samping adanya kesamaan, ada juga pengalaman beragama yang tidak ditemukan pada pengalaman beragama dalam penelitian sebelumnya. Pengalaman tersebut meliputi adanya masa transisi, hilangnya rasa keakuan, gangguan mahluk lain, peningkatan penghayatan moral dan ibadah. Tema pengalaman ini sebenarnya tidak khusus hanya pada orang Islam yang melaksanakan chikir saja, tetapi kemungkinan belum teridentifikasi dalam penelitian pada subjek beragama lain. Hal in disebabkan pada umumnya orang Barat mempunyai ikatan yang longgar dengan institusi agama. Mereka pada umumnya lebih menekankan pada penghayatan agama secara personal, sehingga hal-hal yang bersifat ritual tidak dikategorikan sebagai pengalaman beragama.

Penelitian ini juga berhasil mengklasfikasikan pengalaman beragama menjadi empat kelompok berdasarkan keterkaitan pengalaman tersebut dengan aspek kehidupan manusia, yaitu fisıologis, sosial-psikologis, para-psikologis dan spiritual. Klasifikasi ini dapat memberikan masukan baru, mengingat bahwa klasifikasi pengakaman beragama sebelumnya belum mengaitkan dengan aspek "manusia" yang mengalami. Klasifikasi yang dibuat oleh Stark (1965) maupun Margolif dan Elifson (1979) menekankan segi isi dari pengalaman tersebut.

Tema-tema pengalaman beragama yang ditemukan dalam penelitian ini selain dapat diklasifikasikan berdasarkan aspek manusia yang terlibat, temyata dalam pengalaman yang sesungguhnya jug a tidak terpisah se- 
cara diskrit. Maksudnya satu tema berkaitan erat dengan tema yang lain. Misalnya tema (1) munculnya gerakan otomatis, ternyata mempunyai kaitan erat dengan tema (2) penyucian diri. Demikian juga tema (8) hilangnya rasa ke-aku-an pada sebagian besar subjek sering merupakan prasyarat dari timbulnya tema (9) pengalaman penyembuhan. Tetapi karena pada kedua ide tersebut memenuhi kriteria sebagai suatu lema dan karena pada subjek lain tema yang satu bisa muncul terpisah dengan tema berikutnya, maka peneliti memisahkan ide tersebut sebagai dua tema.

\section{PENUTUP}

Hasil penelitian yang menggunakan analisis kualitatif ini perlu ditindaklanjuti dengan penelitian berikutnya yang bersifat kuantitatif. supaya dapat melibatkan subjek yang lebih besar. Di samping itu juga dapat dikaitkan dengan beberapa variabel Iain.

Misalnya membandingkan antara pengaraman beragama antara orang Islam yang melaksanakan dzikir dengan teknik tertentw dan yang tidak. Karena menurut pengama:an peneliti pengalaman beragama tidak hamya dialami oleh orang-orang yang melaksanakan dzikir saja. Selain itu ada kemung- kinan terdapat pengalaman yang spesifik yang dialami orang yang melaksanakan dzikir dengan teknik tertentu pada kelompok tertentu. Pada kelompok lain yang melaksanakan dzikir dengan teknik berbeda kem mungkinan memiliki pengalaman yang berbeda pula. Misalnya, pengalaman timbulnya gerakan otomatis yang ditemui pada kelompok Pengajian Tawakkal belum tentu muncul pada kelompok lain. Oleh karena itu studi banding pengalaman beragama antar keIompok agama akan sangat menarik untuk diteliti.o

\section{DAFTAR PUSTAKA}

Hayes, V.C. 1970. Religious Experience in the World Religion. Bedford Park: The Australian Association for the study of Religion.

Margolif, R.D. \& Elifson, KW. 1979. A Typology a Religious Experiences. In The Journal o Scientific Study in Reli. gion. 18:61-67.

Stark, J. 1965. A Taxonomy of Religous Experiences. In The Journa! of Scientific Study in Religion. V:97-116. 